\title{
DUCHOWNI POWINNI PRACOWAĆ W DOMACH BOŻYCH, A NIE W PARLAMENTACH - Z DZIEJÓW POPRAWKI POSELSKIEJ JÓZEFA PUTKA Z 1920 ROKU W SPRAWIE POZBAWIENIA KSIĘŻY PRAWA WYBIERALNOŚCI DO SEJMU
}

Streszczenie. Artykuł przedstawia dzieje poprawki, zgłoszonej w 1920 r. do sejmowego projektu konstytucji przez posła PSL-Lewicy, Józefa Putka, przewidującej odebranie duchownym wszystkich wyznań biernego prawa wyborczego do sejmu. Autor tej propozycji był czołowym antyklerykałem Sejmu Ustawodawczego, a jego pomysł wpisywał się w antyreligijną retorykę ówczesnej lewicy, dążącej do usunięcia ludzi Kościoła z życia publicznego. Jego radykalna koncepcja nie znalazła się ostatecznie w tekście konstytucji, nie wywołała również szerszej debaty parlamentarnej, była jednak interesującym, a jednocześnie dość mało znanym przykładem poglądów lewicy ludowej na rolę i znaczenie Kościoła katolickiego w społeczeństwie u zarania II Rzeczypospolitej. Poruszany temat nie został dotąd kompleksowo opracowany, a doczekał się jedynie lakonicznych wzmianek w literaturze przedmiotu. Dlatego w artykule przedstawiono całościowo losy wspomnianej poprawki oraz sejmową debatę nad nią, opierając się na materiałach źródłowych w postaci stenogramów i druków Sejmu Ustawodawczego (1919-1922). Artykuł składa się z wprowadzenia, podzielonej na dwa punkty części zasadniczej (życiorys Józefa Putka, szczegółowy opis tytułowej poprawki) oraz podsumowania.

Słowa kluczowe: Józef Putek, prawo wybieralności, Sejm Ustawodawczy, poprawka poselska, II Rzeczpospolita, antyklerykalizm. 


\section{Wprowadzenie}

K

westia możliwości pełnienia przez księży katolickich ważnych funkcji publicznych w naczelnych organach państwa była jednym z ciekawszych problemów związanych z Kościołem, jakie poruszono na forum Sejmu Ustawodawczego. Pewne wątpliwości posłów budziła w tym kontekście możliwość sprawowania przez duchownych mandatów w centralnych instytucjach przedstawicielskich, a zwłaszcza w sejmie jako naczelnym organie ustawodawczym narodu. Poruszenie wspomnianej sprawy właśnie na forum konstytuanty nie może dziwić. Niewątpliwie wpłynęło na to panujące wówczas w tym sejmie przekonanie o szczególnym znaczeniu parlamentu jako demokratycznie wybranej reprezentacji suwerena (narodu), które najdobitniej uzewnętrzniło się w postanowieniach „Małej konstytucji” z 20 lutego 1919 r. (uznanie sejmu za najwyższy organ państwa), a także w pewnym stopniu w przepisach konstytucji z 17 marca 1921 r. (ustanowienie modelu ustrojowego z silną pozycją izby niższej - poselskiej). W naturalny sposób skutkowało ono skupieniem uwagi posłów właśnie na problemach dotyczących kształtu przyszłego parlamentu. Ogromne znaczenie miały również bieżące doświadczenia płynące z politycznej i społeczno-zawodowej struktury konstytuanty, w której znalazło się przecież liczne grono księży katolickich. Ich obecność i działalność w ławach poselskich była wówczas tematem nader aktualnym, budzącym wiele emocji i prowadzącym do skrajnych ocen. Kontrowersje wokół postawy sejmowego kleru w latach 1919-1922 przełożyły się zatem na podjęcie dyskusji właśnie nad zakresem praw politycznych duchowieństwa, ogniskując się głównie wokół zagadnienia biernego prawa wyborczego księży do parlamentu.

Niniejszy temat pojawił się na forum sejmowym we wrześniu 1920 r., dzięki posłowi PSL-Lewicy, Józefowi Putkowi, który zgłosił podczas debaty konstytucyjnej Sejmu Ustawodawczego poprawkę do projektu konstytucji, zakładającą odebranie duchowieństwu wszystkich wyznań prawa wybieralności do najważniejszego organu legislatywy. Celem niniejszego artykułu jest całościowe przedstawienie dziejów tejże poprawki oraz rezonansu, jaki wywołała ona w sejmie podczas debaty nad konstytucją. Problem ten nie był dotąd przedmiotem oddzielnych, wyczerpujących studiów, a doczekał się jedynie lakonicznych wzmianek w szerszych tematycznie publikacjach $^{1}$. W związku z tym intencją autora jest kompleksowe omówienie

${ }^{1}$ Vide: S. Krukowski, Geneza konstytucji z 17 marca 1921 r., Warszawa 1977, s. 241; M. Solarczyk, Duchowni katoliccy w parlamencie II Rzeczpospolitej, Warszawa 2002, s. 130; R. Żmuda, Stosunek polskich stronnictw ludowych do Kościoła w latach 1918-1926, „Chrześcijanin w Świecie” 1983, nr 3 (114), s. 35. Uzupełniająco na temat poprawki J. Putka, stosunku 
tematu celem pełnego usystematyzowania zagadnienia oraz uzupełnienia luk badawczych. Posłużyć temu ma prezentowana publikacja, dzieląca się na dwie zasadnicze, merytoryczne części, które poprzedzono krótkim wprowadzeniem oraz zwieńczono podsumowaniem. W części pierwszej, posiłkując się istniejącą literaturą przedmiotu, przedstawiono krótki rys biograficzny postaci J. Putka. Z kolei w części drugiej, opartej głównie na analizie źródeł parlamentarnych w postaci stenogramów i druków Sejmu Ustawodawczego $^{2}$, omówiono obszernie tytułową poprawkę oraz jej sejmowe losy.

\section{Józef Putek (1892-1974) - rys biograficzny}

Józef Putek był działaczem politycznym ruchu ludowego, samorządowcem, społecznikiem i publicystą, znanym ze swego antyklerykalizmu. Urodził się 4 lipca 1892 r. w Wadowicach jako syn drobnego chłopa i zarazem cieśli kolejowego. Z Polskim Stronnictwem Ludowym (PSL) związał się już w trakcie nauki w gimnazjum wadowickim, co skutkowało jego wydaleniem ze szkoły (1907). Naukę kontynuował w gimnazjum św. Anny w Krakowie (1910-1912). W 1912 r. rozpoczął studia na Wydziale Prawa Uniwersytetu Jagiellońskiego, które ukończył w 1920 r., uzyskawszy stopień doktora. W tym samym roku rozpoczął aplikanturę adwokacką. Od $1908 \mathrm{r}$. należał do PSL, po rozłamie w tej partii (grudzień 1913) współtworzył wraz z Janem Stapińskim PSL-Lewicę, od 1914 r. wchodził w skład Rady Naczelnej tego stronnictwa. W latach I wojny światowej działał w Naczelnym Komitecie Narodowym (NKN), jako delegat na powiat wadowicki oraz komisarz polityczny Departamentu Wojskowego NKN. Od 1914 r. aktywnie działał na polu samorządowym, pełniąc różne funkcje publiczne w Choczni w powiecie wadowickim (sekretarz gminy, następnie radny). W latach 1919-1929, przez trzy kadencje, sprawował w tej miejscowości urząd wójta ${ }^{3}$.

ugrupowań lewicy chłopskiej do Kościoła katolickiego oraz ich programu politycznego w omawianym okresie, warto sięgnąć m.in. po następujące pozycje: A. Kołodziejczyk, Ruch ludowy a Kościół rzymskokatolicki w latach II Rzeczypospolitej, Warszawa 2002; idem, Kościół katolicki w myśli politycznej ruchu ludowego w latach 1918-1931 (do powstania Stronnictwa Ludowego), [w:] Chłopi - Naród - Kultura, t. 1: Myśl polityczna ruchu ludowego, red. J. Jachymek, K.Z. Sowa, M. Śliwa, Rzeszów 1996; J. Jachymek, Myśl polityczna PSL Wyzwolenie 1918-1931, Lublin 1983; idem, Polskie Stronnictwo Ludowe Lewica 1913-1924, Lublin 1991.

${ }^{2}$ W każdym przypadku powoływania się w przypisach na wspomniane źródła, korzystano z ich wersji online dostępnej na stronie internetowej Biblioteki Sejmowej. Znajdują się one w zakładce pt. „Parlamentaria polskie 1919-1997”, https://bs.sejm.gov.pl/F/?func=file\&file_ name=find-nowe\&local_base=ars01, dostęp: 10.09.2018.

${ }_{3}^{3}$ M. Witkowski, Trybun ludowy. Rzecz o Józefie Putku, „Wadoviana. Przegląd Historyczno-Kulturalny" 2012, nr 15, s. 75-78; K. Bibrzycki, Putek Józef Aleksy, [w:] Polski Słownik Biograficzny [dalej: PSB], t. 29, Wrocław-Warszawa-Kraków-Gdańsk-Łódź 1986, s. 462-463; Putek 
J. Putek został wybrany posłem do Sejmu Ustawodawczego (1919-1922) z listy PSL-Lewicy. W konstytuancie działał aktywnie w komisjach administracyjnej, prawniczej oraz miejskiej. Ponadto pełnił funkcję sekretarza izby (zasiadał więc w prezydium sejmu), był również wiceprezesem klubu poselskiego PSL-Lewicy. U schyłku sierpnia 1922 r. dokonał w nim secesji (sprzeciwiał się planom zjednoczeniowym PSL, opartym na porozumieniu między J. Stapińskim a Wincentym Witosem) i założył odrębny, liczący czterech posłów klub „Lewicy Ludowej”, współpracujący ściśle z lewicowym PSL „Wyzwolenie”.

W trakcie prac sejmowych J. Putek zabierał chętnie głos w debacie nad konstytucją, szczególnie często wypowiadał się w kwestiach przepisów wyznaniowych i stosunków między Kościołem a państwem. Występował ze zdecydowaną krytyką Kościoła katolickiego i jego hierarchii, sprzeciwiał się jego uprzywilejowaniu w życiu publicznym i państwowym, stawiał się w roli samozwańczego obrońcy ludu polskiego przed nadużyciami i uciskiem ze strony kleru oraz warstw posiadających ${ }^{5}$. Wiele jego mów sejmowych miało więc wyraźny posmak antyklerykalny, budziły one często poważne kontrowersje i burzliwe reakcje na sali sejmowej. J. Putek nie stronił od używania dosadnych określeń (np. w trakcie debaty konstytucyjnej określił polską hierarchię kościelną mianem rzymskich fagasów ${ }^{6}$ ) i kierowania poważnych oskarżeń pod adresem środowisk kościelnych oraz wspierającej je prawicy.

Za dość trafne (choć niepozbawione politycznych uprzedzeń) podsumowanie takiej postawy J. Putka w Sejmie Ustawodawczym, uznać można zjadliwą i ironiczną wypowiedź jednego z posłów chadecji, Ludwika Gdyka, który podczas sejmowej debaty z 6 kwietnia 1922 r. nad wnioskiem Narodowego Zjednoczenia Ludowego o uregulowanie statusu prawnego Kościoła katolickiego (chodziło o zniesienie przepisów pozaborczych nadal krępujących pozycję tego Kościoła), mówił o działaniach posła Lewicy PSL następująco:

Józef Aleksy, [w:] Posłowie i senatorowie Rzeczypospolitej Polskiej 1919-1939. Słownik biograficzny, t. 4: M-P, oprac. P. Majewski, red. nauk. G. Mazur, Warszawa 2009, s. 466.

${ }^{4}$ Putek Józef Aleksy, [w:] Posłowie i senatorowie..., t. 4: M-P, s. 468; J. Jachymek, Polskie Stronnictwo Ludowe Lewica..., s. 109-123; K. Bibrzycki, Putek Józef Aleksy, [w:] PSB, t. 29, s. 463; M. Witkowski, Trybun ludowy..., s. 79-83; J. Hampel, Putek Józef, [w:] Kto był kim w Drugiej Rzeczypospolitej, red. J.M. Majchrowski, Warszawa 1994, s. 407; A. Synowiec, Rzeczywistość polityczna II Rzeczypospolitej w twórczości Józefa Putka, „Studia Historyczne” 2011, R. 54, z. 1 (213), s. 15; A. Ajnenkiel, Historia sejmu polskiego, t. 2, cz. 2: II Rzeczpospolita, Warszawa 1989, s. 287.

${ }^{5}$ M. Witkowski, Trybun ludowy..., s. 83-85.

${ }^{6}$ Sprawozdanie stenograficzne Sejmu Ustawodawczego, 181 posiedzenie z 4.11.1920, łam 22 [dalej zapis skrócony, wedle wzoru: Spr. sten. SU, 181 pos. z 4.11.1920, ł. 22]. 
Ilekroć chodzi o sprawy kościoła katolickiego, w tej chwili wchodzi na trybunę nadzwyczajny mistrz ceremonii p. Putek i wyciąga jakieś zardzewiałe akty i spleśniałe dokumenty oskarżające duchowieństwo katolickie i stawia w stan oskarżenia proboszcza - jako przestępcę, który zawsze i wszędzie dopuszcza się karygodnego przestępstwa, bo zajmuje się polityką ${ }^{7}$.

Antyklerykalizm J. Putka przyniósł mu nawet miano jednego z „osobistych nieprzyjaciół Pana Boga”. Określenie to nadał mu znany korespondent sejmowy, Bernard Singer, który poświęcił obu czołowym antyklerykałom polskiego sejmu - J. Putkowi i socjaliście Kazimierzowi Czapińskiemu, felieton pod wskazanym tytułem (Osobiści nieprzyjaciele Pana Boga) ${ }^{8}$.

Dla pełnego zobrazowania nietuzinkowej postaci, jaką był J. Putek, warto przedstawić jego dalsze losy. W listopadzie 1922 r. został wybrany do sejmu I kadencji z listy PSL „Wyzwolenie”, z której kandydowali działacze „Lewicy Ludowej”. Od 1923 r. był członkiem „Wyzwolenia”, należał do ścisłego kierownictwa partii i odpowiadał za jej program. W latach 1922-1927 prowadził aktywną działalność poselską, udzielając się w trzech komisjach izby i zgłaszając wiele interpelacji. Jego antyklerykalne nastawienie uzewnętrzniło się podczas debaty sejmu z 1925 r. nad ratyfikacją konkordatu, kiedy był jednym z czołowych mówców parlamentarnej lewicy, przeciwnej przyjęciu tej umowy ${ }^{9}$.

W 1928 r. J. Putek został wybrany do sejmu II kadencji, z listy państwowej PSL „Wyzwolenie”. Pracę w komisjach łączył z funkcją wiceprezesa klubu parlamentarnego i partii. W parlamencie lat 1928-1930 należał do czołowych postaci Centrolewu, co sprowadziło nań represje obozu sanacyjnego - w 1929 r. został usunięty z urzędu wójta Choczni. W 1928 r. abp Adam Sapieha obłożył go kościelną klątwą, co wynikało z jego bezpardonowej kampanii prasowej wymierzonej w Kościół i duchowieństwo oraz wieloletniego konfliktu z proboszczem Choczni, ks. Józefem Dunajeckim ${ }^{10}$.

7 Spr. sten. SU, 297 pos. z 6.04.1922, ł. 19.

${ }^{8}$ B. Singer, Od Witosa do Sławka, Warszawa 1990, s. 31-32.

9 A. Synowiec, Rzeczywistość polityczna..., s. 16-18; idem, W kręgu publicystyki Józefa Putka - spór z Kościołem katolickim, „Studia Historyczne” 2014, R. 57, z. 2 (226), s. 229-232; Putek Józef Aleksy, [w:] Posłowie i senatorowie..., t. 4: M-P, s. 468; J. Hampel, Putek Józef, [w:] Kto był kim..., s. 407; M. Witkowski, Trybun ludowy..., s. 86-87.

10 Putek Józef Aleksy, [w:] Posłowie i senatorowie..., t. 4: M-P, s. 466, 468; K. Bibrzycki, Putek Józef Aleksy, [w:] PSB, t. 29, s. 463; M. Witkowski, Trybun ludowy..., s. 88, 90-92. 0 kulisach obłożenia interdyktem oraz o konflikcie między wójtem J. Putkiem a proboszczem Choczni zob. szerzej: M. Witkowski, Wójta Józefa Putka droga do interdyktu. Konflikt między władzami gminnymi a proboszczem w Choczni w świetle dokumentów kościelnych, „Folia Historica Cracoviensia" 2013, t. 19, s. 317-337. 0 sporze tym wspominał również w swym felietonie sejmowym B. Singer, tak charakteryzując postawę J. Putka w trakcie parlamentarnych debat na 
J. Putek był uczestnikiem krakowskiego kongresu Centrolewu z czerwca 1930 r., co skończyło się dlań osadzeniem w twierdzy brzeskiej z innymi liderami opozycji. W procesie brzeskim z 1932 r. został skazany na 3 lata więzienia, ale po apelacji wyrok nie uprawomocnił się. Od $1931 \mathrm{r}$. J. Putek był członkiem zjednoczonego Stronnictwa Ludowego (SL), wszedł też do jego kierownictwa. Ostatecznie w sprawie brzeskiej skazano go wyrokiem sądu apelacyjnego w Warszawie z 1933 r. na 5 lat więzienia z utratą praw publicznych i obywatelskich praw honorowych. Osadzono go w więzieniu w Wadowicach, gdzie przebywał aż do zwolnienia prezydenckim aktem łaski (1933-1934). W 1935 r. J. Putka wybrano na wiceprezesa SL, jednak już w 1938 r. został z tej partii usunięty, za agitowanie przeciwko strajkowi chłopskiemu z 1937 r. W efekcie założył własne ugrupowanie o prosanacyjnym profilu - Związek Polskich Ludowców i dostał się do sejmu V kadencji w zbojkotowanych przez opozycję wyborach z $1938 \mathrm{r}^{11}$

W latach II wojny światowej J. Putek był więziony przez niemieckiego okupanta $^{12}$. Po powrocie do kraju w maju 1945 r. związał się ze współpracującym z komunistami, powojennym Stronnictwem Ludowym. W latach 1946-1948 pełnił funkcję ministra poczt i telegrafów. Był też posłem do Krajowej Rady Narodowej (1945-1947), a w 1947 r. został wybrany do Sejmu Ustawodawczego. W 1950 r. aresztowano go pod zarzutem działalności prosanacyjnej z końca lat trzydziestych i osadzono w więzieniu na ul. Montelupich w Krakowie, gdzie przebywał do stycznia 1952 r., mimo iż chronił go wtedy immunitet poselski. Po krótkim zwolnieniu, został znów aresztowany i osadzony, tym razem w więzieniu mokotowskim w Warszawie (1952-1953). Po wypuszczeniu na wolność nie wrócił już do działalności politycznej, poświęcając się karierze adwokackiej i publicystyce. Zmarł 10 maja 1974 r. w Choczni ${ }^{13}$.

tematy wyznaniowe: „Głos ma poseł Putek. Szybko wskoczył na trybunę. Już ubawił chłopów dykteryjkami o księżach. Już walczy z biskupem krakowskim. Szafuje łaciną dla zaimponowania chłopom. Wreszcie uderza w swego proboszcza z Choczni. Walczy z Bogiem jedynie na terenie Małopolski Zachodniej. Prowadzi nieubłagany bój z tiarą przedstawiciel korony (wójt w gminie) w Choczni. Toczy homerycką walkę o dzwony kościelne" (B. Singer, op. cit., s. 32).

${ }^{11}$ K. Bibrzycki, Putek Józef Aleksy, [w:] PSB, t. 29, s. 463-464; M. Witkowski, Trybun ludowy..., s. 92-94, 99-100; Putek Józef Aleksy, [w:] Posłowie i senatorowie..., t. 4: M-P, s. 466468; J. Hampel, Putek Józef, [w:] Kto był kim..., s. 407.

12 Od 1939 r. J. Putek przebywał w więzieniu przy ul. Montelupich w Krakowie, następnie w Wiśniczu (1939-1940). Później był więźniem obozów koncentracyjnych Auschwitz (1940-1942) i Mauthausen (1942-1945).

${ }^{13}$ M. Witkowski, Trybun ludowy..., s. 100-110; Putek Józef Aleksy, [w:] Posłowie i senatorowie..., t. IV: M-P, s. 467; K. Bibrzycki, Putek Józef Aleksy, [w:] PSB, t. 29, s. 464-465. 
Warto również dodać, że J. Putek przez wiele lat był bardzo aktywny na polu publicystyki. Był autorem licznych książek i broszur na tematy polityczne, samorządowe, historyczne i społeczne, pośród których spora część miała antyklerykalny charakter (choćby wielokrotnie wznawiane: Mroki średniowiecza. Obyczaje, przesądy, fanatyzm i okrucieństwa $w$ dawnej Polsce - I wyd. 1935 r.). Redagował i współtworzył wiele pism i tytułów prasowych, związanych zwłaszcza z lewicą ruchu ludowego. Był choćby redaktorem i wydawcą „Przyjaciela Ludu”, a także prasowych organów PSL „Wyzwolenie” („Chłopski Sztandar”, „Wyzwolenie”). Wydawał również skrajnie antyklerykalny, wymierzony w duchowieństwo dodatek do „Chłopskiego Sztandaru” i „Wyzwolenia”, pt. „Kropidło”14.

\section{Poprawka Józefa Putka i jej sejmowe losy ${ }^{15}$}

J. Putek zgłosił na posiedzeniu plenarnym Sejmu Ustawodawczego z 28 września 1920 r. poprawkę do projektu konstytucji przygotowanego przez Komisję Konstytucyjną i poddanego pod II czytanie. Jak stwierdził, poprawkę tę wniósł już przedstawiciel klubu Lewicy PSL w komisji, lecz mimo to nie została ona wydrukowana w oficjalnym sprawozdaniu z jej prac, zawierającym projekt konstytucji wraz z wnioskami mniejszości ${ }^{16}$. J. Putek wnosił więc, tym razem na plenum izby, o uzupełnienie projektu o nowy art. 24, który miał brzmieć następująco: Posłem nie może być wybrany duchowny jakiegokolwiek wyznania ${ }^{17}$. Propozycja ta odbierała zatem wszelkiemu duchowieństwu bierne prawo wyborcze (prawo wybieralności) do sejmu.

${ }^{14}$ A. Synowiec, $W$ kręgu publicystyki Józefa Putka - spór z Kościołem..., s. 226-227; M. Witkowski, Trybun ludowy..., s. 94-96; Putek Józef Aleksy, [w:] Posłowie i senatorowie..., t. 4: M-P, s. $466-468$.

${ }^{15}$ Niniejsza część artykułu stanowi nieznacznie zmodyfikowany fragment rozdziału IV niepublikowanej pracy magisterskiej, obronionej przez autora we wrześniu 2017 r. w Instytucie Historii Uniwersytetu Jagiellońskiego w Krakowie. Praca pt. Debata w Sejmie Ustawodawczym (1919-1922) nad publicznoprawna i polityczna pozycja Kościoła katolickiego w Polsce, została przygotowana pod kierunkiem prof. Czesława Brzozy. Obecnie autor jest jednak doktorantem na Wydziale Historii i Dziedzictwa Kulturowego Uniwersytetu Papieskiego Jana Pawła II w Krakowie.

${ }^{16}$ Vide: Konstytucja Rzeczypospolitej Polskiej, [w:] Sprawozdanie Komisji Konstytucyjnej o Konstytucji Rzeczypospolitej Polskiej, druk Sejmu Ustawodawczego [dalej: SU] nr 1883.

17 Spr. sten. SU, 168 pos. z 28.09.1920, ł. 10. Por. R. Żmuda, op. cit., s. 35. Warto dodać, że jeszcze dalej idący postulat pozbawienia księży „prawa obejmowania godności poselskiej i urzędów samorządowych", towarzyszący stanowczemu sprzeciwowi wobec jakiejkolwiek aktywności politycznej kleru, sformułowało w późniejszym okresie, w swym programie politycznym z 6 marca 1921 r., stronnictwo PSL „Wyzwolenie” (pkt. 14). Vide: Polskie Stronnictwo Ludowe „Wyzwolenie". Program, Warszawa 1921, s. 14; 1921 marzec 6, Warszawa-Program 
Na tym samym posiedzeniu wnioskodawca starał się obszernie uzasadnić swoją propozycję. Podkreślał, że misja duchownego (zwłaszcza katolickiego) jest $\mathrm{w}$ praktyce niemożliwa do pogodzenia z konstrukcją nowoczesnego mandatu poselskiego (mandat wolny), zgodnie z którym poseł jest przedstawicielem całego społeczeństwa (a nie określonych grup społecznych, które go wybrały), a w wykonywaniu swej funkcji jest całkowicie niezawisły (nie odpowiada w czasie kadencji przed swoimi wyborcami i nie jest związany prawnie ich instrukcjami). J. Putek stwierdzał wprost: Każdy dzień nas poucza, że mandaty poselskie $w$ rękach duchownych przeobrażają się $w$ mandaty imperatywne $w$ całym znaczeniu tego słow ${ }^{18}$. Jego zdaniem swoboda działania duchowieństwa $\mathrm{w}$ parlamencie była krępowana wiążącymi ich przepisami prawa religijnego oraz obowiązkiem posłuszeństwa określonej hierarchii kościelnej. Uwagi te odnosił szczególnie do zasad panujących w Kościele katolickim, który odznaczał się najwyraźniejszą hierarchią godności. Mówca przytaczał przykłady nacisku ze strony władz kościelnych na księży piastujących mandaty poselskie w konstytuancie. Przypominał choćby sytuację lewicowego polityka chłopskiego, ks. Eugeniusza Okonia, który był pociągany do odpowiedzialności kościelnej przez konsystorz biskupi w Przemyślu za swoje przemówienia wygłoszone w sejmie. Poza tym argumentował, że księża zasiadający w Sejmie Ustawodawczym wielokrotnie dawali do zrozumienia, że czują się bardziej przedstawicielami organizacji kościelnej, aniżeli ogółu narodu. Na udowodnienie tej tezy przypominał orędzia sejmowe abp. Józefa Teodorowicza wygłaszane wprost w imieniu episkopatu, a także wypowiedzi ks. Kazimierza Kotuli z debaty sejmowej o reformie rolnej, gdy

jako rzecznik organizacji kościelnej z kodeksem kanonicznym w ręku groził z tej trybuny Sejmowi klątwami, gdyby się odważył wywłaszczyć duchowieństwo świeckie i klasztorne ${ }^{19}$.

Dlatego też J. Putek konstatował:

Duchowni jako posłowie pozostają w tak wielkiej zależności od hierarchii kościelnej i tak ślepo jej ulegają, że mowy być nie może by zdobyć się mogli na samodzielny krok. Każdy krok samodzielny, każdy przejaw wolnej woli spotyka się z oporem i karą przełożonych władz kościelnych. Mandat duchownego jest więc mandatem imperatywnym, wykonywanym tak, jak żąda kuria biskupia ${ }^{20}$.

Polskiego Stronnictwa Ludowego Wyzwolenie, [w:] Programy stronnictw ludowych. Zbiór dokumentów, oprac. S. Lato, W. Stankiewicz, Warszawa 1969, s. 184.

18 Spr. sten. SU, 168 pos. z 28.09.1920, ł. 10.

19 Ibidem, ł. 11.

${ }^{20}$ Ibidem. 
Wnioskodawca zaznaczył też, że aby móc w ogóle kandydować do sejmu, księża potrzebują pozwolenia ze strony biskupa, zatem o ich udziale $w$ wyborach nie decyduje ani ich własna wola ani wola wyborców, a zdanie władz kościelnych ${ }^{21}$.

J. Putek twierdził również, że następuje proces biurokratyzacji kleru, który staje się z wolna kategorią urzędników kościelno-państwowych płatnych ze skarbu Państwa ${ }^{22}$. W związku z tym porównywał odebranie duchownym prawa wybieralności do podobnych regulacji z projektu konstytucji dotyczących stricte urzędników państwowych, które zakazywały im kandydowania z okręgu swej właściwości służbowej, w celu uniknięcia potencjalnych nadużyć wyborczych (poprzez wykorzystywanie posiadanej w danym okręgu władzy administracyjnej do wpływania na wyniki wyborów). Sugerował wręcz, że i w przypadku księży istnieje porównywalne ryzyko nadużywania posiadanego stanowiska do agitacji politycznej, czego dowodzić miały liczne sytuacje z okresu wyborów do konstytuanty, gdy kler wykorzystywał środki religijne (np. agitacja podczas kościelnych kazań) do propagandy wyborczej ${ }^{23}$.

Ponadto J. Putek powoływał się na liczne przykłady innych krajów, gdzie ograniczono możliwość sprawowania funkcji przedstawicielskich przez duchownych. Podkreślał w ten sposób, że proponowana przezeń regulacja nie stanowi żadnej nowinki ustrojowej, a wręcz przeciwnie, „pójdzie za wzorem wypróbowanych konstytucji wielu innych państw". Wymieniał przykłady: Anglii (niewybieralność do Izby Gmin duchownych anglikańskich, prezbiteriańskich i rzymskokatolickich posiadających wyższe święcenia kapłańskie), Francji (niemożność kandydowania dostojników Kościoła w okręgach, na które rozciągała się ich jurysdykcja kościelna), Belgii (posłem nie mógł być duchowny, pobierający wynagrodzenie od państwa), a także Meksyku, Szwajcarii, Włoch (niewybieralność duchownych do parlamentu) i Węgier (odebranie prawa wybieralności zakonnikom) ${ }^{24}$. Z uwagi na powyższe, J. Putek apelował o przyjęcie swej poprawki nie tylko „w interesie publicznym”, ale wręcz $w$ interesie wszystkich wyznań, których duchowni powinni pracować w Domach Bożych, a nie w parlamentach ${ }^{25}$. Kończąc swe wystąpienie, skrytykował rząd Jędrzeja Moraczewskiego za to, iż w ordynacji wyborczej do Sejmu Ustawodawczego nie pozbawił kleru biernego prawa wyborczego,

${ }^{21}$ Ibidem.

${ }^{22}$ Ibidem, ł. 12. O wypłacaniu uposażenia duchowieństwu ze środków publicznych w okresie przed konkordatem zob. szerzej: J. Wisłocki, Uposażenie Kościoła i duchowieństwa katolickiego w Polsce 1918-1939, Poznań 1981, s. 211-219.

${ }^{23}$ Spr. sten. SU, 168 pos. z 28.09.1920, ł. 12-13.

${ }^{24}$ Ibidem, ł. 13. Por. M. Solarczyk, op. cit., s. 130.

${ }^{25}$ Spr. sten. SU, 168 pos. z 28.09.1920, ł. 13. 
gdyż jak stwierdził: z pewnościq uniknęlibyśmy $w$ tym Sejmie wielu tarć $i$ intryg, których źródłem sq zasiadający tu przedstawiciele duchowieństwa ${ }^{26}$.

Do poprawki J. Putka odniósł się na bieżąco jedynie ks. Kazimierz Lutosławski, poseł Związku Ludowo-Narodowego (klub parlamentarny endecji). Nie komentował jednak merytorycznej zawartości zgłoszonego wniosku, a jedynie starał się sprostować komentarze tego posła dotyczące wynagradzania księży z państwowej kasy. Nie zgadzając się z wypowiedzią przedmówcy, podkreślił on niewspółmierność tych wynagrodzeń w stosunku do wartości zagrabionych przez zaborcę tzw. dóbr pokościelnych ${ }^{27}$, które nadal pozostawały we władaniu państwa i nie zostały zwrócone Kościołowi ${ }^{28}$.

Poprawka J. Putka nie uzyskała poparcia większości sejmu. Została odrzucona $\mathrm{w}$ trakcie głosowania nad pierwszymi trzema rozdziałami projektu konstytucji, które odbyło się na posiedzeniu izby z 21 października $1920 \mathrm{r}$. Wtedy też zmieniono jej numerację, przyporządkowując ją do wniosków rozpatrywanych przy głosowaniu nad art. 14, następującym bezpośrednio po przepisie o biernym prawie wyborczym do sejmu (art. 13). Nad poprawką posła J. Putka odbyło się wówczas głosowanie imienne, w którym została ona wyraźnie odrzucona przez izbę (za głosowało tylko 91 posłów, przeciwko aż 249) ${ }^{29}$.

Mimo odrzucenia poprawki J. Putka, do sprawy wrócono incydentalnie w toku dalszej debaty prowadzonej w ramach II czytania projektu konstytucji, a dokładniej podczas dyskusji nad rozdziałem $V$ tego aktu. 0 poprawce tej wspominał bowiem w swym przemówieniu z 4 listopada 1920 r. poseł chadecji, Artemiusz Ludomił Czerniewski. Podobnie do posłów lewicy, również on deklarował się jako przeciwnik klerykalizmu, rozumianego jako uczynienie z duchowieństwa uprzywilejowanej społecznie kasty. Jednocześnie podkreślał, że duchowny jest takim samym obywatelem jak każdy inny, a skoro kler w przeszłości istotnie zasłużył się dla państwa polskiego, to teraz nie wolno mu uszczuplać jego praw obywatelskich, jak to poseł Putek tego żąda ${ }^{30}$. Mówca nawiązywał w ten sposób do pomysłu ograniczenia praw politycznych księży, zgłoszonego przez posła Lewicy PSL. Ustosunkował się do niego zdecydowanie negatywnie, stojąc na stanowisku równego traktowania wszystkich obywateli, w tym także osób duchownych.

26 Ibidem.

27 Na temat kwestii dóbr pokościelnych vide np.: K. Chylak, Układy o ziemskich marnościach. Kościół katolicki wobec problemów odzyskania i redystrybucji dóbr duchownych w Polsce w latach 1918-1925, Łódź 2009, passim.

28 Spr. sten. SU, 168 pos. z 28.09.1920,ł. 14-15. Por. S. Krukowski, Geneza konstytucji..., s. 241.

29 Spr. sten. SU, 176 pos. z 21.10.1920, ł. 21, 40-46.

30 Spr. sten. SU, 181 pos. z 4.11.1920, Ł. 18. 
Co ciekawe, do poruszonej przez J. Putka kwestii nie powrócono już podczas III czytania projektu konstytucji. Jego klub nie zdecydował się na ponowne zgłoszenie przygotowanej przezeń poprawki ani w trakcie ostatnich prac Komisji Konstytucyjnej z lutego-marca $1921 \mathrm{r}^{31}$, ani też później, na plenum sejmu. W związku z tym omówiona koncepcja nie była dyskutowana $w$ trakcie finalnych prac sejmowych nad konstytucją, a pomysł odebrania duchownym wszystkich wyznań biernego prawa wyborczego do parlamentu nie został wprowadzony na gruncie ustawy zasadniczej z 17 marca $1921 \mathrm{r}^{32}$ Jak pokazała późniejsza praktyka ustrojowa, duchowni chętnie korzystali z pozostawionej im w ten sposób możności kandydowania do parlamentu i sprawowania w nim mandatów. Dowodzi tego w zasadzie stała obecność księży (zwłaszcza katolickich) w obu izbach parlamentu polskiego kolejnych kadencji, aż do samego końca II Rzeczypospolitej ${ }^{33}$.

\section{Podsumowanie}

Choć poprawka J. Putka nie zyskała sobie uznania sejmowej większości i nie została wprowadzona w ustawie zasadniczej, to jednak stanowiła istotny wyraz nastawienia części polskiej sceny politycznej (a pośrednio także społeczeństwa) do aktywności przejawianej przez kler w sferze polityki, polegającej przykładowo na działalności jego reprezentantów w ławach poselskich. Poprawka ta wpisywała się bowiem w wyraźnie antyklerykalne stanowisko ówczesnej lewicy, potępiającej wszelki udział duchowieństwa w tej sferze życia publicznego oraz dążącej do zmniejszenia społecznych wpływów Kościoła w Polsce, poprzez ograniczenie jego aktywności wyłącznie do sfery prywatnej. Korespondowało to ściśle z lansowanym przez ugrupowania lewicowe przekonaniem, zgodnie z którym religia stanowić miała wyłącznie prywatną sprawę sumienia każdego człowieka i, jako taka, nie powinna oddziaływać na kształt życia społecznego odrodzonej Polski. Jak pokazywała zresztą argumentacja przedstawiona w sejmie przez samego wnioskodawcę, jego propozycja, choć nominalnie dotyczyła wszystkich wyznań, w rzeczywistości wymierzona była głównie przeciwko duchowieństwu katolickiemu oraz wpływom tego Kościoła w Polsce.

31 Vide: Konstytucja Rzeczypospolitej Polskiej, [w:] Sprawozdanie Komisji Konstytucyjnej o Konstytucji Rzeczypospolitej Polskiej, druk SU nr 2561, s. 9.

${ }^{32}$ Ustawa z dnia 17 marca 1921 r. Konstytucja Rzeczypospolitej Polskiej (Dz.U. RP z 1921 r. Nr 44, poz. 267).

${ }^{33} \mathrm{Na}$ temat liczby duchownych katolickich w ławach parlamentarnych w poszczególnych kadencjach zob. szerzej: M. Solarczyk, op. cit., s. 6, 62-97, 421. Por. T. Rek, «O cześć wam panowie prałaci... », „Prawo i Życie” 16.11.1958, R. 3, nr 23 (67), s. 8. 
Warto jednocześnie zauważyć, iż promowany przez J. Putka pomysł został uznany za zbyt kontrowersyjny i daleko idący, czego wyraźnie dowodzi niewielka skala poparcia podczas sejmowego głosowania nad tą kwestią (za pomysłem głosowali niemal wyłącznie posłowie lewicowi, nie angażując się zresztą w żaden inny, wyraźny sposób w poparcie inicjatywy J. Putka na forum izby) oraz brak szerszej debaty parlamentarnej nad poprawką (zabrakło choćby wypowiedzi popierających z trybuny sejmowej ze strony ugrupowań lewicy), która w zasadzie sprowadzała się do monologu samego wnioskodawcy, szeroko uzasadniającego swą propozycję. Wydaje się, iż zwyciężyło wówczas przekonanie, wynikające z żywych w społeczeństwie nastrojów demokratycznych, że nadrzędną wartość w życiu publicznym winna stanowić zasada równości obywateli wobec prawa. Tej z kolei nie dało się logicznie pogodzić z koncepcją całkowitego pozbawienia kleru biernego prawa wyborczego, ograniczającą znacząco zakres praw politycznych tej grupy obywateli. Podkreślić więc należy, że in statu nascendi II Rzeczypospolitej zwyciężyła, przynajmniej w tym przypadku, idea szeroko pojętego demokratyzmu, nie pozwalającego, mimo ówczesnych kontrowersji związanych z łączeniem sfer religii i polityki przez duchowieństwo, na jawne dyskryminowanie w kwestii praw wyborczych kogokolwiek spośród polskich obywateli. Fakt ten świadczyć może niewątpliwie na korzyść zarówno odrodzonego państwa polskiego, jak i posłów konstytuanty, na których barkach spoczywało niezwykle odpowiedzialne i trudne zarazem zadanie zbudowania trwałych fundamentów prawnych oraz właściwego urządzenia nowej Polski po długim okresie narodowej niewoli.

\section{BIBLIOGRAFIA}

\section{Źródła}

Druki Sejmu Ustawodawczego RP (1919-1921).

Dziennik Ustaw RP 1921.

Polskie Stronnictwo Ludowe „Wyzwolenie”. Program, Warszawa 1921.

Programy stronnictw ludowych. Zbiór dokumentów, oprac. S. Lato, W. Stankiewicz, Warszawa 1969. Singer B., Od Witosa do Sławka, Warszawa 1990.

Sprawozdania stenograficzne z posiedzeń Sejmu Ustawodawczego RP (1919-1921). 


\section{Opracowania}

Ajnenkiel A., Historia sejmu polskiego, t. 2, cz. 2: II Rzeczpospolita, Warszawa 1989.

Bibrzycki K., Putek Józef Aleksy, [w:] Polski Słownik Biograficzny, t. 29, Wrocław-WarszawaKraków-Gdańsk-Łódź 1986.

Chylak K., Układy o ziemskich marnościach. Kościół katolicki wobec problemów odzyskania i redystrybucji dóbr duchownych w Polsce w latach 1918-1925, Łódź 2009.

Jachymek J., Myśl polityczna PSL Wyzwolenie 1918-1931, Lublin 1983.

Jachymek J., Polskie Stronnictwo Ludowe Lewica 1913-1924, Lublin 1991.

Kołodziejczyk A., Kościół katolicki w myśli politycznej ruchu ludowego w latach 1918-1931 (do powstania Stronnictwa Ludowego), [w:] Chłopi - Naród - Kultura, t. 1: Myśl polityczna ruchu ludowego, red. J. Jachymek, K.Z. Sowa, M. Śliwa, Rzeszów 1996.

Kołodziejczyk A., Ruch ludowy a Kościół rzymskokatolicki w latach II Rzeczypospolitej, Warszawa 2002.

Krukowski S., Geneza konstytucji z 17 marca 1921 r., Warszawa 1977.

Kto był kim w Drugiej Rzeczypospolitej, red. J.M. Majchrowski, Warszawa 1994.

Posłowie i senatorowie Rzeczypospolitej Polskiej 1919-1939. Słownik biograficzny, t. 4: M-P, oprac. P. Majewski, red. nauk. G. Mazur, Warszawa 2009.

Rek T., «O cześć wam panowie prałaci...», „Prawo i Życie”, 16.11.1958, R. 3, nr 23 (67).

Solarczyk M., Duchowni katoliccy w parlamencie II Rzeczpospolitej, Warszawa 2002.

Synowiec A., Rzeczywistość polityczna II Rzeczypospolitej w twórczości Józefa Putka, „Studia Historyczne" 2011, R. 54, z. 1 (213).

Synowiec A., W kręgu publicystyki Józefa Putka - spór z Kościołem katolickim, „Studia Historyczne" 2014, R. LVII, z. 2 (226).

Wisłocki J., Uposażenie Kościoła i duchowieństwa katolickiego w Polsce 1918-1939, Poznań 1981.

Witkowski M., Trybun ludowy. Rzecz o Józefie Putku, „Wadoviana. Przegląd Historyczno-Kulturalny" 2012, nr 15.

Witkowski M., Wójta Józefa Putka droga do interdyktu. Konflikt między władzami gminnymi a proboszczem w Choczni w świetle dokumentów kościelnych, „Folia Historica Cracoviensia” 2013, t. 19.

Żmuda R., Stosunek polskich stronnictw ludowych do Kościoła w latach 1918-1926, „Chrześcijanin w Świecie" 1983, nr 3 (114). 
Pawet Magiera

\title{
THE CLERGYMEN SHOULD WORK IN THE HOUSE OF GOD NOT IN THE PARLIAMENT - THE HISTORY OF THE JÓZEF PUTEK'S PARLIAMENTARY AMENDMENT FROM 1920 THAT DEPRIVED THE CLERGY OF THEIR PASSIVE SUFFRAGE
}

\begin{abstract}
$\mathrm{T}$
he article presents history of the amendment which was proposed in 1920 as a part of parliamentary project of constitution by deputy Józef Putek, a member of Polish Peasant Party - Left. Through this amendment he wanted to deprive the clergy of all confessions of their passive suffrage to the parliament. The author of this proposition was one of the leading anticlerical deputies in the Legislative Sejm. His idea was a part of the wider discourse of then left-wing parties which sought to eliminate clergy from the public life. This radical concept was not implemented in the constitution and did not lead to the wider discussion in parliament. However, this amendment was an interesting but simultaneously little-known example of the opinions of peasant's left on the role and relevance of the Catholic Church in the polish society in the beginning of the Second Polish Republic. This topic was not presented so far in a complex way. There were only some short references in a previous literature. Therefore, the article shows comprehensively a history of the Józef Putek's amendment and the debate about it which took place in the parliament. The article based on historical sources which are stenographic records and documents of the Legislative Sejm (1919-1922). It contains an introduction, main part which is divided into two sections (biography of Józef Putek and then the description of his amendment) and a summary.
\end{abstract}

Keywords: Józef Putek, passive suffrage, the Legislative Sejm, parliamentary amendment, the Second Polish Republic, anticlericalism. 